\title{
Türkiye'deki Olası Lojistik Üs Yerlerinin Seçilmesi İçin Karşılaştırmalı Bir Analiz
}

\section{A Comparative Analysis for Selecting Possible Logistics Base Locations in Turkey}

Devran Yazır 1,*iD, Bekir Sahin ${ }^{1,2}$

${ }^{1}$ Karadeniz Technical University, Surmene Faculty of Marine Sciences, 61530, Trabzon, TURKEY

${ }^{2}$ Norwegian University of Science and Technology, Department of Computer Science, 2802 Gjøvik, NORWAY

Sorumlu Yazar / Corresponding Author*: dyazir@ktu.edu.tr

Geliş Tarihi / Received: 29.11.2019

Kabul Tarihi / Accepted: 10.06.2020

DOI:10.21205/deufmd.2020226626

Atıfșsekli/How to cite: YAZIR, D., SAHIN, B., (2020).Türkiye'deki Olası Lojistik Üs Yerlerinin Seçilmesi İçin Karşılaştırmalı Bir Analiz. DEUFMD 22(66), 929-940.

\section{Öz}

Türkiye, Asya ve Avrupa arasında büyük bir jeopolitik konuma sahip olduğundan, konumu lojistik operasyonlar için önemli bir rol oynamaktadır. Bu çalıșmada, Türkiye'de kurulması muhtemel bir lojistik üs için önceden tanımlanmış lokasyonları değerlendirmek amaçlı karşılaştırmalı bir analiz yapılmaktadır. Küresel ticaretin rekabet avantajını elde etme gerekliliklerini yerine getirmek için, lojistik üs kurma kararları altyapı, talep, dıs çevre, arz, ekonomi ve topoğrafik konum gibi çeşitli faktörlerden etkilenir. Bu çalışma, uzman görüşleri alındıktan sonra sonra karar kriterlerini ve olası alternatif yerleri saptamaktadır. Türkiye bir yarımada olduğundan, deniz ulaşımına öncelik verilerek, denize erişimi olan olası altı șehir belirlenmiștir. Verilen kriterler çerçevesinde lojistik üs oluşturma kararları için en iyi seçeneği belirlemek amacıyla analitik hiyerarşi süreci yöntemi uygulanmaktadır. Sonuçta belirlenen alternatiflerden lojistik üs için en iyi seçeneğin İstanbul olduğu tespit edilmiștir. Bursa'nın İstanbul'dan sonra daha öncelikli olması beklenirken, Karadeniz'in merkezi ve ulaşım yollarının kesişim noktası oluşundan dolayı uzmanlar tarafından Samsun ikinci olarak tercih edilmştir.

Anahtar Kelimeler: Lojistik Üs, Analitik Hiyerarși Süreci, Karar Matrisi, Tutarlılık Oranı

\begin{abstract}
Turkey has a great geopolitical position located between Asia and Europe, its location plays a significant role for logistics operations. In this study, we consider a comparative analysis to evaluate the predefined locations for possible logistics bases in Turkey. In order to fulfill the requirements of global trade to obtain a competitive advantage, decisions on a logistics base development are influenced by several factors such as infrastructure, demand, external environment, supply, economy and topographical location. This study determines decision criteria and possible alternative locations after conducting several expert consultations. Since Turkey is a peninsula, six possible cities that have access to the sea are determined by prioritizing the maritime transportation. An analytical hierarchy process method is implemented to select the best option for the logistics base decisions under given criteria. As a result, it is determined that Istanbul is the best option for logistics base. While Bursa is expected to be a top priority after Istanbul, Samsun is preferred by the experts as the second option because it is the intersection point of the Black Sea and the transportation routes.
\end{abstract}

Keywords: Logistics Base, Analytic Hierarchy Process, Decision Matrix, Consistency Ratio 


\section{Introduction}

The concept of logistics is the name given to the activities of planning, implementation and controlling the forward and reverse flow and storage of cargoes, services and information from the origin to the end to fulfil the customer satisfaction [1]. The need to transport natural resources to the world as a result of people's desire to see other countries and the efforts of people to go to places in daily life has emerged. Transportation has gained a different dimension with the intensification of the competition of enterprises that want to meet the increasing consumer demands. The concept of logistics is constantly developing in parallel with the developing technology in the modern sense. The concept of logistics base includes many different logistics activities such as transportation, distribution, cargo handling, separation of products, subject to customs procedures, export and import activities, infrastructure, insurance and guarantee coverage, guidance and raw material procurement [2,3]. To determine a logistics base, all activities between countries are carried to and from one center depend on all methods of transportation (sea, airway or highway). Therefore, the cities we determine in this study are made by considering the maritime transportation. When the logistics base is being determined, the location must have certain criteria to be selected of which these criteria should provide that the location will be the logistics base and will continue to be a logistics base.

These considerations fall into six criteria:

- Infrastructure criterion; the locations include regions with the best access to the sea, air, road, pipeline, telecommunication, logistics parks, distribution centers, terminals, and warehouses.

- The external-environment criterion; investment environment, taxation, distribution center, labor, and storage costs of the selected place.

- Supply criterion; these activities include logistics service providers, logistics companies, transport business organizers, third party logistics activities, carriers, customs brokers, warehouses, warehouse operators and terminal line services.
- Demand criterion; demand criterion includes activities such as economy, population, consumption, globalization, sellers, buyers, manufacturing sector and technology.

- Topographical structure criterion; it includes geopolitical location, ease of transportation, easy access to raw material, hinterland area, accessible through the land, air, and rail.

- Economy criterion; this criterion includes contributing to the growth of foreign trade and the increase of foreign capital earned by the country.

The logistics base is selected based on the abovementioned criteria. The location of a logistics base in Turkey is selected under these predetermined criteria. Turkey's geopolitical location in Asia is located in the center between Europe and Africa. Because three-fourths of the area is surrounded by sea, locations such as the Black Sea, Mediterranean, and North Africa are accessible by both water and air. Apart from this, Balkans, the Caucasus and the Middle East countries are accessible through land, air and railway which are considered very important. If we also look to Turkey, we can find crossroads between north-south and east-west. Although Turkey has all the advantages of economic development, trade growth is not brought it to the desired goal where there are many factors that influence these outcomes. For instance, the production factors and the factors of production efficiency do not increase, the real national income does not increase in the long term. Inadequacy of inventions by giving importance to research and development activities and lack of adequate logistics base. Therefore, the necessary measures cannot be applied at the required time. The structure we call logistics base does not only realize logistics activities, it also plays an active role in the growth of economy and trade. Moreover, it contributes to the growth of foreign trade and the increase in the foreign capital earned by the country. Considering Turkey, ports and airports in Istanbul, Izmir, Mersin, and Samsun own their international logistics bases which are examined, one result suggests that they are able to function in a better way. It is seen that the services given to the countries of the region as well as the domestic and international transport from these ports are very narrow and are limited in a certain group of products. Because these 
centers do not have the necessary infrastructure and they are not supported by adequate logistics bases, they can serve narrow spaces. Economic growth cannot reach the desired levels by transportation to narrow spaces. Large areas need to be serviced to reach the desired economic goals. Therefore, there is a need for logistics bases built in a comprehensive, equipped, suitable area to support these centers. In this study, an application has been made to guide building logistics bases for suitable places. In this study, Analytical Hierarchy Process (AHP) method is applied to reveal the best option for selecting the location of the logistics base in Turkey. Six criteria and six alternatives are determined based on the expert consultations. An online questionnaire is prepared and delivered via emails and social media. The experts are asked to compare criteria and alternatives based on given criteria. Judgments of eleven experts are collected and the data are processed via spreadsheet tool of AHP method.

The paper is organized as follows. Literature Review is given in Section2. Methodology is provided in Section 3. Section 4 indicates the application step by step. In section 5 , results, discussion and conclusions are given.

\section{Literature Review}

Logistics is directly influencing and stimulating the economy of a country. The countries that are economically strong are determined by trade, import, and export. Parallel to the growth of trade, the logistics sector is one of the main arteries for the development of a country's economy [2]. If Turkey's economy reaches to an advanced level of logistics operations, it will provide important benefits to approach world standards. Economists have emerged Turkey's market which will provide national manufacturers and exporters with many benefits in terms of logistics [3]. Turkish logistics sector, as far as it is today, has a potential in the international dimension not only serves the national logistics needs but also adds a very serious economic plus value to the country's economy [4]. The modern logistics system and logistics park are important nodes in the logistics industry. Turkey is now seen as a new potential for boosting the progress of the urban and regional economy [5]. The biggest advantage of Turkey as a logistics base is the geopolitical position. On this subject, Saraçoğlu made a statement about Turkey geopolitical position, opening the way for the well-being centers in the logistics sector, as he did in many other areas [6]. In addition, the location of Turkey allows someone to see Turkey as a bridge between the continents of Europe, Asia, and in his work, Karataş stated that the establishment of transport means linking Africa as well [7]. Kara et al., (2009) stated that the countries with a large geographical area, such as Turkey is essential to have coordination between all transport systems [8]. On the other hand, Bayraktutan and Özbilgin found the following information; logistics centers should be supported with logistics potential investment [9]. It is very important to have advantages other than the geographical position advantage. Infrastructure of Turkey outside the geographical position should be appropriate [10]. The geographical advantage for a country's logistics is unfortunately not enough alone, physical and institutional sub-structures are important at least as geography [11]. On the other hand, it is not possible to benefit from the advantages of geographical location and young population of Turkey, when there are lack of infrastructure, laws and policy, as well as lack of a master plan prepared for the sector [12]. There is a need for a logistics master plan that will regulate the logistics industry, public institutions, and the private sector must have a say in the relevant regulations. Turkey needs to develop their technology as well as their physical infrastructure [13]. Turkey needs to develop technologies for information and communication which are considered another important element that allows the development of the logistics industry in terms of employment and infrastructure [14]. Physical infrastructure in the area of logistics in Turkey can easily use all types of transportation and must have a technological infrastructure [15]. The logistics areas should be supported by advanced warehouses, infrastructure, handling systems and information technologies in order to increase the efficiency of the transfer time of the freight, decrease the costs and to complete the supply chain by presenting the product at the shortest time [16]. It is important to note that logistics centers are designed to be suitable for intermodal or multimodal transport in order to earn a true logistics center name or to be located at such a convenient location for such transportation. Moreover, superior logistics coordination should be established in Turkey, and procurement and marketing should be 
supported by qualified people [17]. In order to minimize logistics costs, a haulier must be a part of the logistics network, the number, and capacity of its logistics centers, and the transportation network [18]. Gui et al., used system dynamics to analyze the logistics system of the work area, and said that it creates a system dynamics model for the field of logistics. The field of logistics system is based on the characteristics of the system dynamics [19]. Logistics activities indicate that physical distribution costs in enterprises can reach up to $30 \%$ of their sales [20]. We need to improve our registries both quantitatively and qualitatively, that our legislation has many shortcomings and that warehouses are inadequate [21]. The impact of innovation indicators in EU countries on logistics performance was analyzed in 2009. Correlation analysis shows that human resources and intellectual assets have a positive effect on the logistics performance of countries [22]. Logistics performance index of Turkey were compared with Eurasian countries. In a study done in 2012, Turkey's comparative advantage in logistics activities is remarkable [23]. Ateş and Işık have analyzed the impact on the developments in export logistics services in Turkey. As a result of the Granger causality analysis, there is a doublecausality relationship between the logistics sector and the exports [24]. Çekerol and Kurnaz examined the effects of the global crisis on the logistics sector. During and after the crisis, if companies improve information infrastructure and reduce their costs and need for qualified personnel, logistics performance will increase [25]. Logistics sectors of Hungary, Romania and Turkey have been compared to observe the level of development. Turkey's is also supremacy over these countries, there is close cooperation among the countries concerned [26].

The difference of this study from the existing studies in the literature is that the neighborhood of the cities to the sea is taken as basis in determining the alternatives. Our aim in this study is to include a maritime perspective in the decision-making process to establish a logistics base. As far as we know, there exist no such studies in the literature.

\section{Methodology}

\subsection{Analytical hierarchy process}

Perspectives of people to the solutions of a problem can often change depending on their way of thinking. Particularly, taking into account the perspectives of people about the decision process can directly affect the effectiveness and the shape of the decision. Because the criteria for different decision-making are different, their level of importance and options can change. One of the different methods used to improve the effectiveness of decisions in such situations is AHP. AHP is a mathematical method that computes variables in the format of crisp or linguistic values by several pairwise comparisons of an individual or a group judgment [27]. In this way, more effective ways can be provided to find solutions for these decision problems [28-30]. The AHP allows modeling in a hierarchical structure that shows the relationship between decision makers' complex problems, the main objective of the problem, criteria, sub-criteria and alternatives [31]. Recently, this method has attracted a lot of attention, and became used in the solution of many decision-making problems in real life. The AHP consists of four steps: The first step of the hierarchical structure is taken by determining the criteria and the sub criteria of these criteria based on the expert evaluations [32-34]. When this process is carried out, the results of quantitative and qualitative analysis become available to specialists to make their decisions. In stage 2, two comparison matrices are introduced to determine the significance levels between criteria and sub criteria [35, 36].

These comparison matrices are $\mathrm{n} \times \mathrm{n}$ square matrices as shown in Equation 1:

$$
A=\left[\begin{array}{llll}
a_{11} a_{12} & \ldots & a_{1 n} \\
a_{21} a_{22} & \ldots & a_{2 n} \\
\cdot & & & \cdot \\
\cdot & & \cdot \\
\cdot & & & \cdot \\
a_{n 1} a_{n 2} & \ldots & a_{n n}
\end{array}\right]
$$

$A$ is the matrix components on the diagonal of this matrix has a value of 1 if $i=j$. Because in this case the relevant factor is compared by itself. The comparisons of the factors are done in an interrelated manner and mutually depending on which one is more important than the other [37, 38]. After this comparison is carried out, the importance scale recommended by Saaty as in Table 1 is used. 
DEÜ FMD 22(66), 929-940, 2020

Table 1. Priority scale.

\begin{tabular}{|c|l|}
\hline $\begin{array}{c}\text { Priority } \\
\text { Values }\end{array}$ & Value Definitions \\
\hline 1 & Both criteria are equal. \\
\hline 3 & $\begin{array}{l}\text { First criterion is more prior than the } \\
\text { second. }\end{array}$ \\
\hline 5 & $\begin{array}{l}\text { First criterion is very prior than the } \\
\text { second. }\end{array}$ \\
\hline 7 & $\begin{array}{l}\text { First criterion has a very strong priority } \\
\text { compared to the second }\end{array}$ \\
\hline 9 & $\begin{array}{l}\text { First criterion has absolute priority over } \\
\text { the second. }\end{array}$ \\
\hline $2,4,6,8$ & Intermediate values. \\
\hline
\end{tabular}

$(i=2, j=4)$ is 5 , the fourth row is in the second column component $(i=4, j=2)$ value of the comparison matrix is $1 / 5$. In terms of accuracy of the comparison matrices, it is possible to predict a common judge about the researcher during the studies, and sometimes it can be done by taking the geometric average of personal judgments. In the third phase, the normalization of the relation matrices occurs. In this process, first, as shown in Equation 2, each matrix is obtained by dividing the sum of the column by the values of all the column elements.

$$
B_{i}=\left[\begin{array}{c}
b_{11} \\
b_{21} \\
\cdot \\
\cdot \\
\cdot \\
b_{n 1}
\end{array}\right] \quad b_{i j}=\frac{a_{i j}}{\sum_{i=1}^{n} a_{i j}}
$$

The values of each row are then summed and divided by the matrix size to determine the weight percent weights $\left(w_{i}\right)$ for each criterion. The operations to be performed are as in Equation 3:

$$
C=\left[\begin{array}{lrrr}
b_{11} & b_{12} & \ldots & b_{1 n} \\
b_{21} b_{22} & \ldots & b_{2 n} \\
\cdot & & \cdot \\
\cdot & & \cdot \\
\cdot & & \cdot \\
b_{n 1} & b_{n 2} & \ldots & b_{n n}
\end{array}\right] w_{i}=\frac{\sum_{j=1}^{n} c_{i j}}{n}
$$

Following these calculations, decision criterion, criterial weight points and criterion scores of decision options according to each decision criterion are obtained together with $\mathrm{K}$ decision matrix.

$$
\mathrm{s}_{\mathrm{i}}=\left[\mathrm{s}_{\mathrm{ji}}\right]_{\mathrm{mx} 1} \rightarrow \mathrm{K}=\left[\mathrm{s}_{\mathrm{ij}}\right]_{\mathrm{mxn}}
$$

Finally, the percentage distribution of the resultant decision points by multiplying the decision matrix $\mathrm{W}$ by the column vector is obtained.

$$
\left[\mathrm{S}_{\mathrm{ij}}\right]_{\mathrm{m} \times \mathrm{n}} \times\left[\mathrm{W}_{\mathrm{i}}\right]_{\mathrm{n} \times 1}
$$

Now, the order of importance of decision options can be made to start with a large overall score. In the last stage, all pairwise comparisons are the consistency of the judgment formulated by the decision maker during the process. Consistency is considered as a prerequisite for rational thinking [31, 39]. Therefore, the consistency of the matrices obtained should be examined. Consistency is determined by the calculation of the Consistency Ratio developed by Saaty $[32,40]$.

$$
\lambda \max =\left[W_{i}\right]_{n \times 1} \times\left[a_{i j}\right]_{n \times n}
$$

where, $\lambda \max$ is the relative weight of the matrix.

$$
T_{i}(\text { Consistency Index })=(\lambda \max -\mathrm{n}) /(\mathrm{n}-1)
$$


DEÜ FMD 22(66), 929-940, 2020

RTi (Random Consistency Index) is shown in Table 2.

Table 2. Random consistency index.

\begin{tabular}{|l|l|l|l|l|l|l|l|l|l|l|}
\hline $\mathbf{n}$ & 1 & 2 & 3 & 4 & 5 & 6 & 7 & 8 & 9 & 10 \\
\hline $\boldsymbol{R} \boldsymbol{T}_{\boldsymbol{i}}$ & 0 & 0 & 0.52 & 0.89 & 1.11 & 1.25 & 1.35 & 1.40 & 1.45 & 1.49 \\
\hline
\end{tabular}

where, $\mathrm{T} 0=\mathrm{Ti} / \mathrm{RT}$ takes place.

Low consistency indicates that the decision maker's decisions in the pairwise comparisons are consistent, and high if they are inconsistent. For this reason, the method predicts that the Consistency Ratio is less than 0,10. If this ratio is greater than 0.10 , Saaty and Vargas recommend decision makers to review their decision [4146].

\section{Application}

In this study, AHP method is applied to reveal the best option for selecting the location of the logistics base in Turkey. Six criteria and six alternatives are determined based on the expert consultations (Figures 1 and 2).

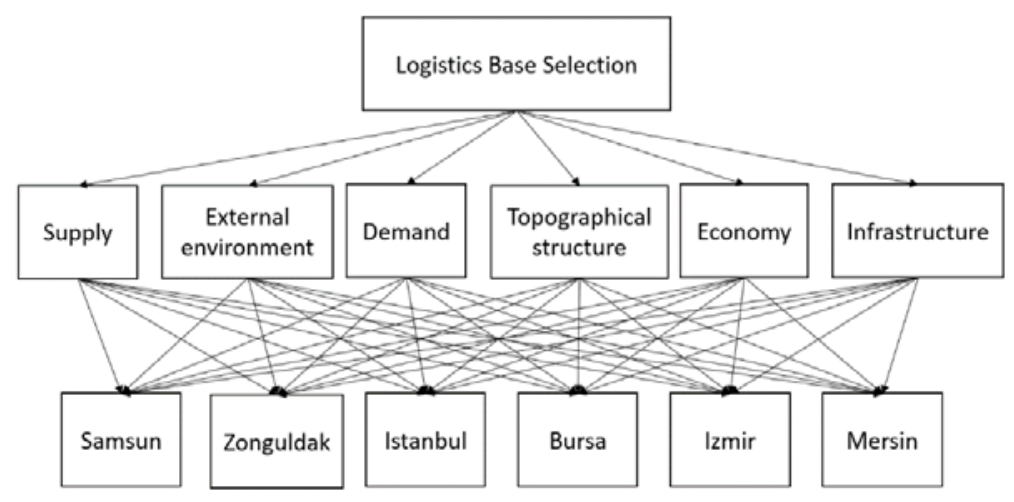

Figure 1. The structure of the proposed logistics base selection

\begin{tabular}{|c|c|c|c|c|c|}
\hline \multirow{2}{*}{$\begin{array}{l}\text { Goal } \\
\text { Goal } \\
\end{array}$} & 다무 & Criteria & 10म & \multicolumn{2}{|c|}{ Alternatives $\mathrm{CD}+$} \\
\hline & \multirow[t]{4}{*}{ पव } & $D$ & ( & & \\
\hline & & $E$ & 10 & Istanbul & 10 \\
\hline & & $E E$ & त田 & Izmir & ㄷㅁ밈 \\
\hline & & $I$ & 10 & Mersin & 20 \\
\hline$\Theta$ & Add Node... & $\boldsymbol{\theta}$ & Add Node... & $\hat{\theta}$ & d Node... \\
\hline
\end{tabular}

Figure 2. Super Decisions framework of the proposed model

An online questionnaire is prepared and delivered via-emails and social media. The experts are asked to compare each criterion and each alternative based on given criterion. Judgments of eleven experts are collected and the data are processed via Super Decisions software and spreadsheet tool of AHP method. Table 3 shows the aggregated inter-criteria evaluations. 
Table 3. Aggregated evaluation matrix for criteria.

\begin{tabular}{|l|l|l|l|l|l|l|}
\hline & S & EE & D & TS & E & I \\
\hline Supply (S) & 1.00 & 1.52 & 2.21 & 1.83 & 1.21 & 1.55 \\
\hline External Environment (EE) & 0.66 & 1.00 & 3.06 & 2.64 & 2.33 & 1.72 \\
\hline Demand (D) & 0.45 & 0.33 & 1.00 & 2.56 & 0.79 & 1.19 \\
\hline Topographical Structure (TS) & 0.55 & 0.38 & 0.39 & 1.00 & 1.48 & 1.77 \\
\hline Economy (E) & 0.83 & 0.43 & 1.27 & 0.68 & 1.00 & 2.01 \\
\hline Infrastructure (I) & 0.64 & 0.58 & 0.84 & 0.56 & 0.50 & 1.00 \\
\hline
\end{tabular}

The Table 4 and Table 9 provide the expert judgement matrices of alternatives under predefined criteria. For example, Table 4 gives the aggregated evaluation matrix of alternatives based on Supply criterion. Other criteria such as
External Environment, Demand, Topographical Structure, Economy and Infrastructure are considered in the Tables 5, 6, 7, 8 and 9 respectively.

Table 4. Aggregated evaluation matrix of alternatives based on Supply criterion.

\begin{tabular}{|c|c|c|c|c|c|c|}
\hline & Samsun & Zonguldak & Istanbul & Bursa & Izmir & Mersin \\
\hline Samsun & 1.00 & 3.12 & 1.04 & 1.64 & 1.29 & 1.60 \\
\hline Zonguldak & 0.32 & 1.00 & 1.03 & 0.51 & 0.71 & 1.29 \\
\hline Istanbul & 0.96 & 0.97 & 1.00 & 4.94 & 3.12 & 5.36 \\
\hline Bursa & 0.61 & 1.96 & 0.20 & 1.00 & 0.61 & 1.78 \\
\hline Izmir & 0.77 & 1.42 & 0.32 & 1.63 & 1.00 & 3.79 \\
\hline Mersin & 0.63 & 0.77 & 0.19 & 0.56 & 0.26 & 1.00 \\
\hline
\end{tabular}

Table 5. Aggregated evaluation matrix of alternatives based on External Environment criterion.

\begin{tabular}{|l|l|l|l|l|l|l|}
\hline & Samsun & Zonguldak & Istanbul & Bursa & Izmir & Mersin \\
\hline Samsun & 1.00 & 2.52 & 1.14 & 1.25 & 0.76 & 1.78 \\
\hline Zonguldak & 0.40 & 1.00 & 0.76 & 0.83 & 1.01 & 1.10 \\
\hline Istanbul & 0.88 & 1.31 & 1.00 & 3.95 & 3.29 & 4.93 \\
\hline Bursa & 0.80 & 1.21 & 0.25 & 1.00 & 0.85 & 1.61 \\
\hline Izmir & 1.32 & 0.99 & 0.30 & 1.18 & 1.00 & 3.18 \\
\hline Mersin & 0.56 & 0.91 & 0.20 & 0.62 & 0.31 & 1.00 \\
\hline
\end{tabular}

Table 6. Aggregated evaluation matrix of alternatives based on Demand criterion.

\begin{tabular}{|l|l|l|l|l|l|l|}
\hline & Samsun & Zonguldak & Istanbul & Bursa & Izmir & Mersin \\
\hline Samsun & 1.00 & 2.45 & 0.56 & 1.27 & 1.70 & 1.69 \\
\hline Zonguldak & 0.41 & 1.00 & 0.87 & 1.78 & 1.55 & 0.97 \\
\hline Istanbul & 1.78 & 1.15 & 1.00 & 3.53 & 2.99 & 3.77 \\
\hline Bursa & 0.79 & 0.56 & 0.28 & 1.00 & 0.44 & 2.08 \\
\hline Izmir & 0.59 & 0.65 & 0.33 & 2.26 & 1.00 & 3.48 \\
\hline Mersin & 0.59 & 1.03 & 0.27 & 0.48 & 0.29 & 1.00 \\
\hline
\end{tabular}


DEÜ FMD 22(66), 929-940, 2020

Table 7. Aggregated evaluation matrix of alternatives based on Topographical Structure criterion.

\begin{tabular}{|l|l|l|l|l|l|l|}
\hline & Samsun & Zonguldak & Istanbul & Bursa & Izmir & Mersin \\
\hline Samsun & 1.00 & 2.58 & 1.53 & 1.28 & 2.20 & 1.78 \\
\hline Zonguldak & 0.39 & 1.00 & 2.36 & 1.96 & 2.01 & 2.07 \\
\hline Istanbul & 0.65 & 0.42 & 1.00 & 3.55 & 2.33 & 4.08 \\
\hline Bursa & 0.78 & 0.51 & 0.28 & 1.00 & 1.08 & 1.45 \\
\hline Izmir & 0.45 & 0.50 & 0.43 & 0.93 & 1.00 & 2.74 \\
\hline Mersin & 0.56 & 0.48 & 0.25 & 0.69 & 0.36 & 1.00 \\
\hline
\end{tabular}

Table 8. Aggregated evaluation matrix of alternatives based on Economy criterion.

\begin{tabular}{|l|l|l|l|l|l|l|}
\hline & Samsun & Zonguldak & Istanbul & Bursa & Izmir & Mersin \\
\hline Samsun & 1.00 & 3.36 & 0.89 & 1.27 & 1.36 & 2.00 \\
\hline Zonguldak & 0.30 & 1.00 & 1.00 & 1.38 & 0.72 & 2.00 \\
\hline Istanbul & 1.12 & 1.00 & 1.00 & 4.74 & 3.11 & 4.15 \\
\hline Bursa & 0.79 & 0.73 & 0.21 & 1.00 & 1.35 & 3.12 \\
\hline Izmir & 0.74 & 1.39 & 0.32 & 0.74 & 1.00 & 4.09 \\
\hline Mersin & 0.50 & 0.50 & 0.24 & 0.32 & 0.24 & 1.00 \\
\hline
\end{tabular}

Table 9. Aggregated evaluation matrix of alternatives based on Infrastructure criterion.

\begin{tabular}{|l|l|l|l|l|l|l|}
\hline & Samsun & Zonguldak & Istanbul & Bursa & Izmir & Mersin \\
\hline Samsun & 1.00 & 1.77 & 0.52 & 1.23 & 0.27 & 1.05 \\
\hline Zonguldak & 0.56 & 1.00 & 0.53 & 1.87 & 1.55 & 1.61 \\
\hline Istanbul & 1.91 & 1.87 & 1.00 & 4.39 & 2.94 & 4.64 \\
\hline Bursa & 0.81 & 0.53 & 0.23 & 1.00 & 1.16 & 2.09 \\
\hline Izmir & 3.67 & 0.65 & 0.34 & 0.86 & 1.00 & 2.87 \\
\hline Mersin & 0.95 & 0.62 & 0.22 & 0.48 & 0.35 & 1.00 \\
\hline
\end{tabular}

Table 10 presents final weights and consistency ratio of criteria and alternatives. The weights of each criterion are found as Supply-0.24, External Environment-0.26, Demand-0.13, Topographical Structure-0.12, Economy-0.14 and Infrastructure is 0.10. Final weights of alternatives for each criterion and consistency ratio of each matrix can also be found in Table

10. As it is seen all matrices are less than 0.1 thus, it can be concluded as all matrices are consistent. According to final result, the weights of alternatives (Samsun, Zonguldak, Istanbul, Bursa, Izmir, Mersin) are calculated as 0.21, 0.14, $0.30,0.12,0.16$ and 0.07 respectively. Table 10 also shows the consistency ratio:

Table 10. The weights and consistency ratio of criteria and alternatives. Final results and rank of alternatives.

\begin{tabular}{|l|l|l|l|l|l|l|l|l|}
\hline & S & EE & D & TS & E & I & CR & \\
\hline & 0.24 & 0.26 & 0.13 & 0.12 & 0.14 & 0.10 & $6 \%$ & \\
\hline & & & & & & & Final Result & Rank \\
\hline Samsun & 0.22 & 0.20 & 0.20 & 0.25 & 0.22 & 0.12 & 0.21 & 2 \\
\hline Zonguldak & 0.11 & 0.12 & 0.15 & 0.21 & 0.14 & 0.16 & 0.14 & 4 \\
\hline Istanbul & 0.31 & 0.31 & 0.31 & 0.22 & 0.30 & 0.36 & $\mathbf{0 . 3 0}$ & $\mathbf{1}$ \\
\hline Bursa & 0.12 & 0.13 & 0.11 & 0.11 & 0.13 & 0.12 & 0.12 & 5 \\
\hline Izmir & 0.17 & 0.16 & 0.15 & 0.12 & 0.15 & 0.17 & 0.16 & 3 \\
\hline Mersin & 0.07 & 0.08 & 0.08 & 0.08 & 0.06 & 0.08 & 0.07 & 6 \\
\hline CR & $10 \%$ & $7 \%$ & $7 \%$ & $10 \%$ & $9 \%$ & $8 \%$ & & \\
\hline
\end{tabular}


DEÜ FMD 22(66), 929-940, 2020

Sensitivity analysis is conducted by using Super independent variable of Istanbul is shown in Decisions pocket program. As an example, Figure 3.

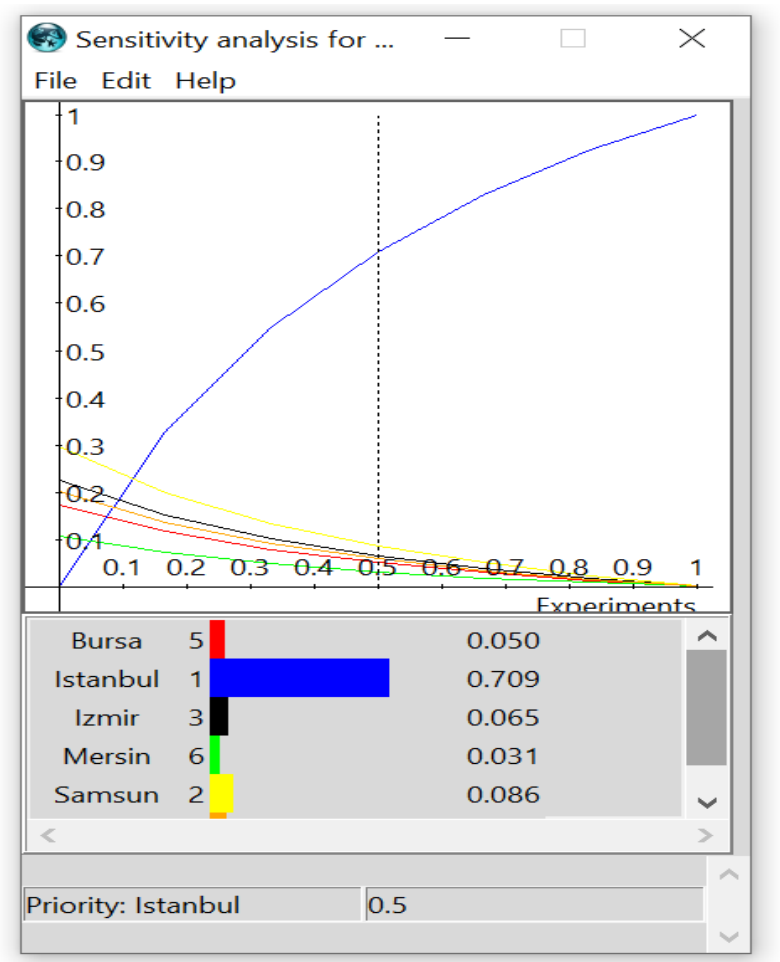

Figure 3. Sensitivity analysis for the independent variable of Istanbul
Since independent variables and their weights change, importance of alternatives and their priorities tend to change. It is observed that the rankings for Istanbul and Mersin do not change. In general, if independent variables change, the general rankings mostly preserve their positions. Sensitivity analysis for all independent variables are provided in Table 11. 
DEÜ FMD 22(66), 929-940, 2020

Table 11. Sensitivity analysis for the AHP results.

\begin{tabular}{|c|c|c|c|c|c|c|c|c|c|c|c|c|}
\hline & \multicolumn{12}{|c|}{ Independent Variable } \\
\hline & \multicolumn{2}{|l|}{ Bursa } & \multicolumn{2}{|c|}{ Istanbul } & \multicolumn{2}{|l|}{ Izmir } & \multicolumn{2}{|l|}{ Mersin } & \multicolumn{2}{|c|}{ Samsun } & \multicolumn{2}{|c|}{ Zonguldak } \\
\hline & Weigh & Ran & Weigh & Ran & Weigh & Ran & Weigh & Ran & Weigh & Ran & Weigh & Ran \\
\hline Bursa & 0.681 & 1 & 0.05 & 5 & 0.045 & 5 & 0.042 & 6 & 0.047 & 5 & 0.044 & 5 \\
\hline Istanbul & 0.11 & 2 & 0.709 & 1 & 0.113 & 2 & 0.107 & 2 & 0.117 & 2 & 0.112 & 2 \\
\hline Izmir & 0.057 & 4 & 0.065 & 3 & 0.686 & 1 & 0.055 & 4 & 0.06 & 3 & 0.057 & 4 \\
\hline Mersin & 0.027 & 6 & 0.031 & 6 & 0.028 & 6 & 0.675 & 1 & 0.029 & 6 & 0.027 & 6 \\
\hline Samsun & 0.074 & 3 & 0.086 & 2 & 0.076 & 3 & 0.072 & 3 & 0.693 & 1 & 0.075 & 3 \\
\hline Zongulda & 0.051 & 5 & 0.058 & 4 & 0.052 & 4 & 0.049 & 5 & 0.054 & 4 & 0.684 & 1 \\
\hline
\end{tabular}

\section{Results, Discussion and Conclusions}

Generally speaking, multiple factors influence the establishment of a logistics base. Infrastructure, demand, external environment, supply, economy, and topographical structure play an active role on a logistics base. The criteria should be determined in order to be considered as a logistical superiority. The city which is preferred must have all these factors. The cities that we pass through are predominantly determined by being close to the sea and being active in the sea route. On the other hand, cities that were determined are close to neighboring countries. As a result of the surveys we have conducted, Istanbul city was selected as the most suitable logistics base. Experts' tendency show Istanbul is the most suitable city due to the geopolitical position, development of infrastructure, availability of supply chain, high demand, and efficient supply. We consider people's economy as the most important criteria among others. When we look at Istanbul, we see Istanbul is a bridge between two continents. Therefore, investors and foreign capitalists play an important role in choosing Istanbul. Samsun was chosen as the second logistics base. Though Samsun is less developed than Bursa and İzmir in terms of development and infrastructure maintenance, it is still ahead. This is because Samsun is located in the Black Sea region, and maritime transport might be used effectively. Another advantage of the city of Samsun is that the other cities in the Black Sea region are centralized. This is a major contribution to the region's supply chain. İzmir is observed as the third logistics base in Turkey. The development status of İzmir has an effect on this result. Another reason is that its geographical location is close to European countries. İzmir was chosen as the third logistics province despite its logistics position, and it is higher than Samsun in population. This is due to the fact that Samsun has more logistics activities than İzmir and İzmir is considered a tourist city. The fourth logistics base is Zonguldak. The most important advantage of Zonguldak is its underground mines and the marine transportation that develops continuously. Bursa has been chosen as the fifth logistics base. Bursa is a major contributor to agricultural activities. The geopolitical position of Bursa behind Zonguldak and Samsun is a big influence. Bursa looks more like an inner-city. Lastly, Mersin has been chosen as the sixth logistics base. Although Mersin has an advantage due to its location, it shines behind other cities. It is due to the situation of other countries in the Mediterranean region where are close to Mersin. They have also inadequate infrastructure. A place cannot be linked to a single criterion when choosing a logistics base. It is necessary that the determined criteria are related to each other and work in a systematic way. In the literature, Turkey's geopolitical position is mentioned over and over. When researchers see it as incomplete, they point out that it is necessary to have qualified staff and personnel, besides, infrastructure and logistics activities are inadequate. Investigations reveal that Turkey has lacking logistics activities for a good economy, even the geopolitical position seems to be an excellent logistics base. On the other hand, Turkey does not have enough infrastructure and lack of relevant academic studies are big problems as well. Turkey has prospered economically in recent years and can set up logistics bases with established adequate infrastructure. A logistics base to be built will boost the country's economy and might bring it to the level of developed countries. 
In the future, this study can be implemented with different methods to compare the results. After the coronavirus (COVID 19) effect, it will be determined whether the structure of the cities will change in terms of logistics base. Practical applications will be compared with the results of the study.

\section{Acknowledgement}

This work was supported in part by European Research Consortium for Informatics-ERCIM. We thank Assoc. Prof. Dr. Ahmet Soylu for his support and guidance during the ERCIM programme. We would like to thank to Editor and anonymous reviewers for their help to improve this manuscript. We also appreciate $3 \mathrm{rd}$ Mate Nizamettin Cabaka and anonymous experts for their kind help during this study.

\section{References}

[1] Council of Supply Chain Management Professionals (CSCMP) Supply Chain Management Definitions and Glossary, August 2013.

[2] Akın, E. 2012. Türkiye, Lojistik Üs Olabilir. http://www.turkishtimedergi.com/genel/turkiyelojistik-us-olabilir/( Erişim Tarihi: 04.01.2019).

[3] Cevik, S., Kaya, S. 2010. Türkiye'nin Lojistik Potansiyeli ve İzmir'in Lojistik Faaliyetleri Açısından Durum (SWOT) Analizi: IZTO Ar-Ge Bülten, Kasım.

[4] Kılınç, N. 2005. Türkiye'nin Bulunduğu Bölge İtibariyle Lojistik Üs Olma Potansiyeli: Türk Asya Stratejik Araştırmalar Merkezi, Eylül.

[5] Ma, L., Huang, T. 2008. System Dynamics Analysis on the Evolution of Logistics Cluster, In Service Operations and Logistics, and Informatics, vol. 2, 2853-2857.

[6] Saraçoğlu, C. 2017. Türkiye Lojistik Üssü. https://www.yenisafak.com/ekonomi/turkiyelojistik-ussu-2649077 (Erișim Tarihi: 04.01.2019).

[7] Karataș, İ.A. 2017. Bazı Avrupa Ülkeleri ile Türkiye'nin Lojistik Sektörünün Karşılaştırmal Analizi, Journal of Academic Approaches, vol. 8(1), 122

[8] Kara, M., Tayfur, L., Basık, H. 2009. The Importance of Logistics Centers in Global Trade and Turkey, Mustafa Kemal University Journal of Social Sciences Institute, vol. 6(11), 69-84.

[9] Bayraktutan, Y., Özbilgin, M. 2014. The Determination of Logistic Center Investment Levels of The Cities in Turkey By Using Fuzzy Logic, Erciyes Üniversitesi İktisadi ve İdari Bilimler Fakültesi Dergisi, 43, 1-36.

[10] Uzunkaya, Ö. 2014. Türkiye'de Lojistiğin Yarını. http://lojistikkulubu.ist/turkiye-de-lojistigin-yarini (Erişim Tarihi: 04.01.2019).
[11] Öner, S. 2014. Dünyada ve Türkiye'de Lojistik Sektörü. https://webnak.com.tr/blog/lojistiksektoru (Erişim Tarihi: 04.01.2019).

[12] Kutlu, S., Gür, F.A. 2008. Lojistik Master Planı ve Bir Lojistik Üs Olarak Türkiye, Mevzuat Dergisi, vol. 11(129), 1306-1306.

[13] Emre, A. 2014. Dünyada ve Türkiye'de Lojistik Üs Mevzuat. http://www.lojistikhatti.com (Erişim Tarihi: 04.01.2019).

[14] Dașkan, E.S. 2016. Türkiye'de Lojistik Sektörünün Gelişi ve Gelecek Öngörüleri: İstanbul Ticaret Üniversitesi, Dış Ticaret Enstitüsü, Tartışma Metinleri, Working Paper Series.

[15] Erkan, B. 2014. Logistics Sector and Competitiveness in Turkey: ASSAM International Refereed Journal, vol. 1(1), $44-65$.

[16] Aydın, G.T., Ögüt, K.S. 2008. Lojistik köy nedir?: 2. Uluslar arası Demiryolu Sempozyumu, İstanbul, 2, 1439-1448.

[17] Yücel, A. N. 2016. Türkiye'de Lojistik Merkez Kavramı. https://tr.linkedin.com/pulse (Erişim Tarihi: 04.01.2019).

[18] Chen, X., Zhou, M. 2010. Design and Simulation of a Logistics Network for a Telecom Products Supply Application: a Case Study, International Journal of Industrial Engineering, 17(2), 80-91.

[19] Gui, S., Zhu, Q., Lu, L. 2005. Area Logistics System Based on System Dynamics Model, Tsinghua Science \&Technology, 10(2), 265-269.

[20] Şen, İ.K. 2014. Lojistik Faaliyetlerin Yönetimi ve MaliyetlemeYaklassımları, Cankırı Karatekin Üniversitesi İktisadi ve İdari Bilimler Fakültesi Dergisi, 4(1), 83-106.

[21] Cınar, H. 2011 Lojistik üs: Türkiye. https://www.dunya.com/kose-yazisi/lojistik-usturkiye/9679 (Erişim Tarihi: 04.01.2019).

[22] Burmaoğlu, S. 2012. Ulusal İnovasyon Göstergeleri ile Ulusal Lojistik Performansı Arasındaki İlişki: AB Ülkeleri Üzerine Bir Araştırma: Ege Akademik Bakış, 12(2), 193-208.

[23] Sofyalıoğlu, Ç., Kartal, B. 2013. Türkiye ve Avrasya Ekonomi Topluluğu Ülkelerinin Lojistik Performans Indekslerinin Karssılasstırılması ve Bazı Cılkarımlar, International Conference on Eurasian Economies, 524-531.

[24] Ates, İ., Ișı, E. 2010. Türkiye'de Lojistik Hizmetlerinin Gelişiminin İhracattaki Büyümeye Etkileri, Ekonomi Bilimleri Dergisi, 2(1), 99-106.

[25] Cekerol, G.S., Kurnaz, N. 2011. Küresel Kıriz Ekseninde Lojistik Sektörü ve Rekabet Analizi, Selçuk Üniversitesi Sosyal Bilimler Enstitüsü Dergisi, 25, 47-59.

[26] Tutar, E., Tutar, F., Yetişen, H. 2009. Türkiye'de Lojistik Sektörünün Gelişmişlik Düzeyinin Seçilmiş $\mathrm{AB}$ Ülkeleri (Romanya ve Macaristan) ile Karşılaştırmalı Bir Analizi, Karamanoğlu Mehmetbey Üniversitesi Sosyal ve Ekonomik Araştırmalar Dergisi, 2009 (2), 190-216.

[27] Sahin, B., Senol, Y.E. 2015. A Novel Process Model for Marine Accident Analysis by Using Generic FuzzyAHP Algorithm, The Journal of Navigation, 68(1), 162-183.

[28] Dağdeviren, M., Akay, D., Kurt, M. 2004. İş Değerlendirme Sürecinde Analitik Hiyerarși Süreci 
DEÜ FMD 22(66), 929-940, 2020

ve Uygulaması, Gazi Üniversitesi Mühendislik ve Mimarlık Fakültesi Dergisi, 19(2), 131-138.

[29] Sahin, B. 2014. Route Selection Problem in the Arctic Region for the Global Logistics Industry, Global Logistics Management, 105.

[30] Şahin, B., Yazır, D. 2019. Uzmanlık Katsayılarının Belirlenmesinde Kullanılan Farklı Yaklașımların Geliştirilmiş Bulanık Analitik Hiyerarşi Süreci Metodu Üzerindeki Etkilerinin Analizi, Journal of the Faculty of Engineering \& Architecture of Gazi University, 34 (1), 89-102.

[31] Kuruüzüm, A., Atsan, N. 2001. The Analytic Hierarchy Process Approach and Its Applications in Business, Akdeniz İktisadi ve İdari Bilimler Fakültesi Dergisi, 1, 83-105.

[32] Toksarı, M. 2007. Analitik Hiyerarşi Prosesi Yaklaşımı Kullanılarak Mobilya Sektörü için Ege Bölgesi'nde Hedef Pazarın Belirlenmesi, Celal Bayar Üniversitesi İktisadi ve İdari Bilimler Fakültesi Yönetim Ekonomi Dergisi, 14(1), 171-180.

[33] Adıgüzel, 0. 2009. Personel Seçiminin Analitik Hiyerarşi Prosesi Yöntemiyle Gerçekleştirilme, Dumlupınar Üniversitesi Sosyal Bilimler Dergisi, 24, 243-251.

[34] Sahin, B., Yip, T.L. 2017. Shipping Technology Selection for Dynamic Capability Based on Improved Gaussian Fuzzy AHP Model, Ocean Engineering, 136, 233-242.

[35] Oğuzlar, A. 2007. Analitik Hiyerarşi Süreci ile Müşteri Şikâyetlerinin Analizi, Akdeniz İktisadi ve İdari Bilimler Fakültesi Dergisi, (14), 122-134.

[36] Sahin, B. 2017. Consistency Control and Expert Consistency Prioritization for FFTA by Using Extent Analysis Method of Trapezoidal FAHP, Applied Soft Computing, 56, 46-54.

[37] Yaralığlu, K. 2001. Performans Değerlendirmede Analitik Hiyerarşi Proses, Dokuz Eylül Üniversites İktisadi ve İdari Bilimler Fakültesi Dergisi, 6(1), 129142.

[38] Sahin, B., Kum, S. 2015. Risk Assessment of Arctic Navigation by Using Improved fuzzy-AHP Approach International Journal of Maritime Engineering, 157(4), 241-250.

[39] Sahin, B., Senol, Y.E., Bulut, E., Duru, O. 2015 Optimizing Technology Selection in Maritime Logistics, Research in Logistics \& Production, 5(3), 299-309.

[40] Saaty, T.L. 2000. Fundamentals of Decision Making and Priority Theory with Analytic Hierarchy Process, AHP Series, Vol: 6, RWS Publications.

[41] Yüksel, İ., Akın, A. 2006. Analitik Hiyerarşi Proses Yöntemiyle İșletmelerde Strateji Belirleme, Doğuş Üniversitesi Dergisi, 7(2), 254-268.

[42] Sahin, B. 2019. Route Prioritization by Using Fuzzy Analytic Hierarchy Process Extended Dijkstra Algorithm, Journal ETA Maritime Science, 7(1), 3-15.

[43] Dündar, S., Ecer, F. 2008. Öğrencilerin GSM Operatörü Tercihinin Analitik Hiyerarşi Süreci Yöntemiyle Belirlenmesi, Celal Bayar Üniversitesi İktisadi ve İdari Bilimler Fakültesi Yönetim Ekonomi Dergisi, 15(1), 195-205.

[44] Şenol, Y.E., Sahin, B., Kum, S. 2013. Marine Accident Analysis by Using Pairwise Comparison, Journal of ETA Maritime Science, 1(2), 59-64.
[45] Saaty,T.L. 1980. The Analytic Hierarchy Process, Mc. Graw Hill, USA

[46] Saaty, T.L. 1985. Analytical Planning, RSW Publication 